\title{
$\mathrm{Fe}-5 \mathrm{Y}_{2} \mathrm{O}_{3}$ 조성의 기계적 합금화 분말에 형성된 산화물의 상변태 거동
}

\author{
김가언 ${ }^{1,2} \cdot$ 최정선 $^{1} \cdot$ 노상훈 $^{1} \cdot$ 강석훈 $^{1} \cdot$ 최병권 $^{1} \cdot$ 김영도 $^{2} \cdot$ 김태규 $^{1, *}$ \\ ${ }^{1}$ 한국원자력연구원 원자력소재개발부 \\ ${ }^{2}$ 한양대학교 신소재공학과
}

\section{Phase Transformation Behavior of Oxide Particles Formed in Mechanically Alloyed $\mathrm{Fe}-5 \mathrm{Y}_{2} \mathrm{O}_{3}$ Powder}

\author{
Ga Eon Kim ${ }^{1,2}$, Jung-Sun Choi ${ }^{1}$, Sanghoon Noh ${ }^{1}$, Suk Hoon Kang ${ }^{1}$, Byoung Kwon Choi ${ }^{1}$, \\ Young Do Kim ${ }^{2}$, and Tae Kyu Kim ${ }^{1, *}$ \\ ${ }^{1}$ Nuclear Materials Development Division, Korea Atomic Energy Research Institute, Deajeon 34057, Republic of Korea \\ ${ }^{2}$ Department of Materials Science and Engineering, Hanyang University, Seoul 04763, Republic of Korea
}

\begin{abstract}
The phase transformation behavior of the oxides formed in mechanically alloyed $\mathrm{Fe}-5 \mathrm{Y}_{2} \mathrm{O}_{3}$ powder is investigated. Non-stoichiometric Y-rich and Fe-rich oxides with sizes of less than $300 \mathrm{~nm}$ are observed in the mechanically alloyed powder. The diffusion and redistribution reactions of the elements in these oxides during heating of the powder above $800{ }^{\circ} \mathrm{C}$ were observed, and these reactions result in the formation of a $\mathrm{Y}_{3} \mathrm{Fe}_{5} \mathrm{O}_{12}$ phase after heating at $1050{ }^{\circ} \mathrm{C}$. Thus, it is considered that the $\mathrm{Y}_{2} \mathrm{O}_{3}$ powder and some $\mathrm{Fe}$ powder are formed from the non-stoichiometric Y-rich and Fe-rich oxides after the mechanical alloying process, and a considerable energy accumulated during the mechanical alloying process leads to a phase transformation of the $\mathrm{Y}$-rich and $\mathrm{Fe}$-rich oxides to $\mathrm{Y}_{\alpha} \mathrm{Fe}_{\beta} \mathrm{O}_{\gamma}$-type phase during heating.
\end{abstract}

(Received September 1, 2016; Received October 19, 2016)

Keywords: ODS(Oxide Dispersion Strengthened), mechanical alloying, nano-sized oxide particle, phase transformation, $\mathrm{Y}_{a} \mathrm{Fe}_{B} \mathrm{O}_{\mathrm{Y}}$-type phase

\section{1. 서 론}

제4세대 미래 원자력시스템인 소듐냉각고속로는 상용 경 수로에 비하여 고온과 고방사선의 가혹한 조건에서 운전되 도록 설계되므로 고강도의 신소재가 요구된다 $[1,2]$. 페라이트 /마르텐사이트계 산회물분산강화(Oxide Dispersion Strengthened, $\mathrm{ODS}$ ) 강은 기지에 고온에서도 열적 안정성이 우수한 산화물 이 미세하게 분산되어 고온 크립 특성과 함께 중성자 조사 저 항성이 우수하다 $[3,4]$. 한국을 포함한 대부분의 소듐냉각고 속로를 개발하는 국가에서는 핵연료의 피복관 소재로 고강 도 ODS 강을 활발하게 개발하고 있다 [5-7].

일반적으로 $\mathrm{ODS}$ 합금의 분산재로 $\mathrm{Y}_{2} \mathrm{O}_{3}$ 산화물이 사용되 고 있으며, 산화물을 미세하게 분산시키기 위하여 기계적 합 금화(Mechanical Alloying, MA) 공정으로 합금 분말을 제조

*Corresponding Author: Tae Kyu Kim

[Tel: +82-42-868-8384, E-mail: tkkim2@kaeri.re.kr]

Copyright (c) The Korean Institute of Metals and Materials
한 다음 후속 열간/냉간 가공 공정을 거쳐 부품으로 제조된다 $[8,9]$. 나노 산화물이 합금 기지에 형성되는 과정을 살펴보면, 기계적 합금화 과정 중에 파쇄와 분해를 반복하면서 비정질 상태로 되었다가 후속 열처리 과정에서 미세산화물로 석출 되어 성장한다는 것으로 알려져 있다 $[10,11]$. 최근에는 Atom Probe Tomography (APT), In-situ Transmission Electron Microscopy(TEM), X-ray Absorption Fine Structure(XAFS) 등과 같은 고분해능 장비가 활용되면서 다양한 연구 결과가 보고되고 있다 [12-16]. 기계적 합금화 과정에서 산화물 결정 구조가 비화학양론적 결합상태가 변화되며 이로 인해 복합 구조의 산화물이 석출된다는 의견이 제시되고 있다 [17-19]. 이와 함께 철계 기계적 합금화 분말에서 형성된 석출물의 미 세조직과 열처리 과정에서 발생되는 결정상이나 결정 구조 의 변화에 대한 연구가 필요한 실정이다 $[20,21]$. 본 연구에서 는 기계적 합금화 공정으로 제조된 $\mathrm{Fe}-5 \mathrm{Y}_{2} \mathrm{O}_{3}$ 합금 분말에 형 성된 나노 산화물의 미세조직을 관찰하고 온도 변화에 따른 산화물의 상변태 거동을 분석하고자 한다. 


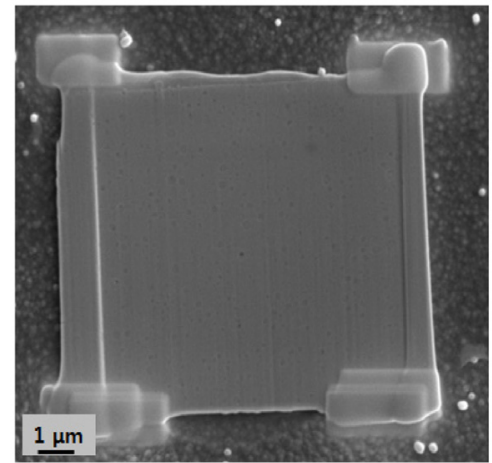

Fig. 1. SEM image of cross section of the mechanically alloyed $\mathrm{Fe}-5 \mathrm{Y}_{2} \mathrm{O}_{3}$ powder prepared by FIB technique.

\section{2. 실험 방법}

\section{1. 시편 준비}

평균입도 $85 \mu \mathrm{m}$ 인 $\mathrm{Fe}$ 분말과 $30 \mathrm{~nm}$ 인 $\mathrm{Y}_{2} \mathrm{O}_{3}$ 분말을 각각 $95 \%$ 와 5\%의 중량비로 준비한 후 고에너지 수평형 볼밀 장비 (모델명 : Simoloyer CM20)을 이용하여 합금 분말로 제조하 였다. 기계적 합금화는 회전속도 $300 \mathrm{rpm}$ 의 조건으로 48 시간 동안 $\mathrm{Ar}$ 분위기에서 수행하였다. 기계적 합금화 공정 중 온 도를 확인하기 위하여 장비 내부에는 열전대를 부착하고 외 부는 냉각수를 순환시켜 일정 온도가 유지될 수 있도록 하였 으며, 공정 중 온도는 $50^{\circ} \mathrm{C}$ 이하를 유지하였다. 제조된 $\mathrm{Fe}-5 \mathrm{Y}_{2} \mathrm{O}_{3}$ 합금 분말은 Focused Ion Beam(FIB, 모델명 : Helios NanoLab ${ }^{\mathrm{TM}}$ ) 방법으로 너비 $10 \mu \mathrm{m}$, 폭 $10 \mu \mathrm{m}$, 두께 50 $\mathrm{nm}$ 이하로 가공한 다음 proto-chip에 준비하였다(그림 1). TEM과 Energy Dispersive X-ray Spectroscopy(EDS) 장비를 이용하여 박막시편의 미세조직을 관찰하였다. In-situ TEM 장비(모델명 : JEM-ARM200F)를 활용하여 진공 분위기에서 상온부터 $1050{ }^{\circ} \mathrm{C}$ 온도까지 가열하여 온도 변화에 따른 합금 분말의 미세조직 변화를 관찰하였다. High Resolution $\mathrm{TEM}(\mathrm{HRTEM})$ 장비를 이용하여 나노크기의 산화물 이미지 를 관찰하고 Selected Area Electron Diffraction(SAED) 패턴 을 분석하였다. Gatan Digital-Micrograph 프로그램을 이용하 여 Fast Fourier Transformation(FFT) 이미지를 indexing하고 나노산화물의 결정구조를 해석하였다 [22,23].

\section{3. 결과 및 고찰}

\section{1. 기계적 합금화 분말의 미세조직}

FIB 방법으로 가공한 $\mathrm{Fe}-5 \mathrm{Y}_{2} \mathrm{O}_{3}$ 합금 분말 단면의 미세조

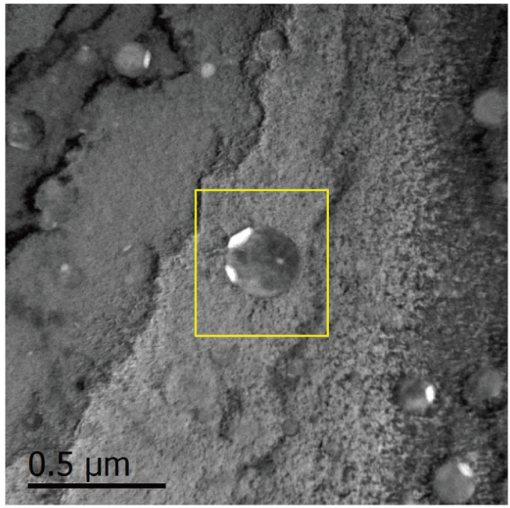

(a)

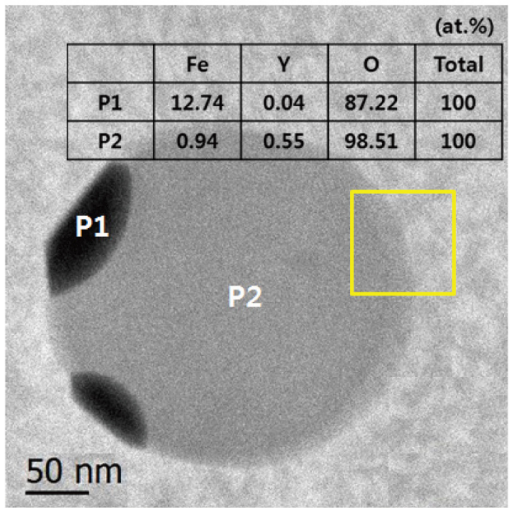

(b)

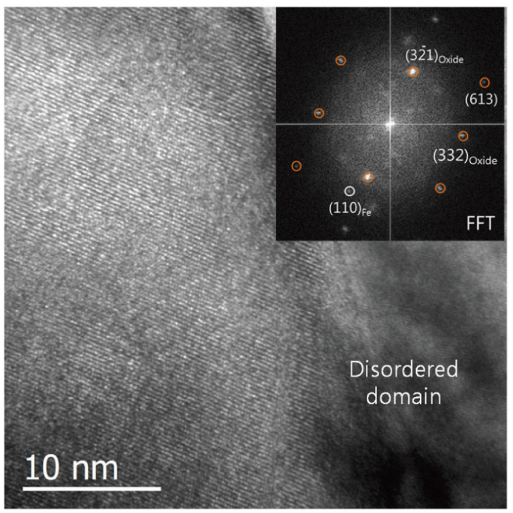

(c)

Fig. 2. TEM/EDS study results of the mechanically alloyed Fe-5 $\mathrm{Y}_{2} \mathrm{O}_{3}$ powder; (a) TEM image of the matrix, (b) TEM image and chemical composition $(\mathrm{P} 1, \mathrm{P} 2)$ of oxide particle marked in (a) and (c) HRTEM image and FFT pattern analysis of the oxide particle marked in (b).

직은 그림 2에서 보이는 바와 같다. 합금 분말 내부에는 상당 량의 기공이 관찰되고 석출물이 비교적 균일하게 분포되어 있는 것으로 나타났다(그림 2(a)). 석출물의 크기는 대략 300 $\mathrm{nm}$ 이하로 관찰되었다. 기계적 합금화 과정에서 $\mathrm{Fe}$ 분말과 $\mathrm{Y}_{2} \mathrm{O}_{3}$ 분말은 파쇄, 분해 및 냉간 용접 과정이 반복되고 합금 


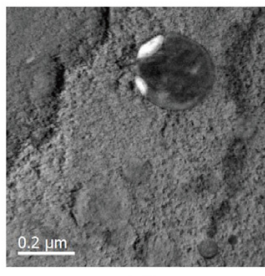

(a)

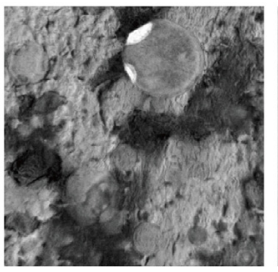

(d)
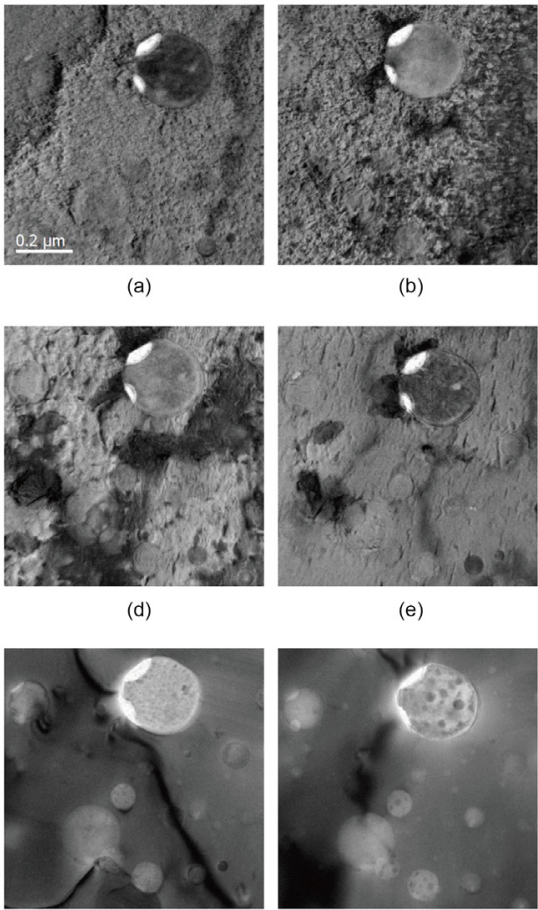

(b)

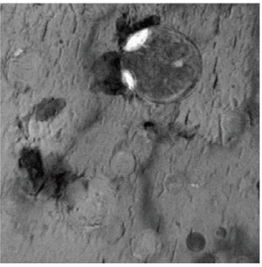

(e)
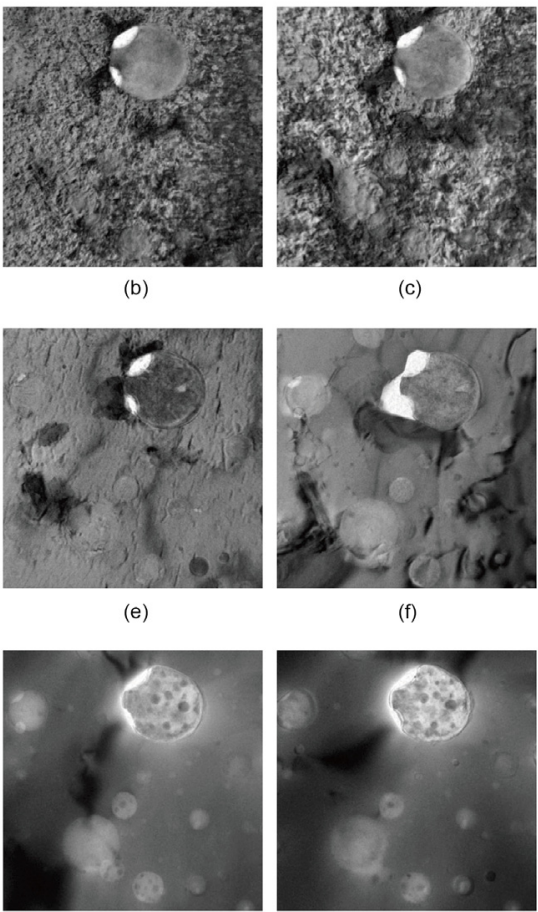

(c)

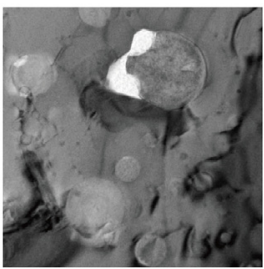

(f)

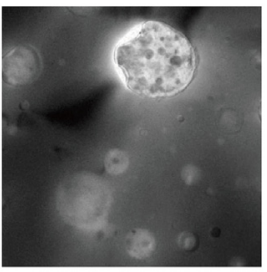

Fig. 3. In-situ TEM images of the mechanically alloyed $\mathrm{Fe}-5 \mathrm{Y}_{2} \mathrm{O}_{3}$ powder after heating at (a) 25, (b) 100, (c) 500, (d) 600, (e) 700, (f) 800, (g) 900, (h) 1000 and (i) $1050{ }^{\circ} \mathrm{C}$.

화가 진행되면서 다량의 기공이 형성된 것으로 판단된다. 기 지에 분산되어 있는 석출물 대부분은 구형에 가까운 형태였 지만 가장자리 일부분에서 전자빔 투과 시 발생되는 원소 종 류에 따른 명암 차이가 관찰되었다(그림 2(b)). 이러한 입자 들은 Y-rich 및 Fe-rich 두 종류의 화학 성분으로 구성되어 있 는 산화물로 분석되었고 이와 같은 산화물 입자는 기지에 전 체적으로 분포되어 있었다. 기계적 합금화 공정은 높은 에너 지 가공으로 분말들을 물리적으로 충돌시켜 파쇄하고 강제 적으로 혼합되는 과정을 반복하면서 합금 분말이 제조된다. 이 과정에서 $\mathrm{Fe}$ 분말과 $\mathrm{Y}_{2} \mathrm{O}_{3}$ 분말은 나노 크기의 입자로 미 세화되고 Y-rich, Fe-rich 두 종류의 성분으로 구성된 산화물 이 기지에 분산되는 것으로 판단된다. 기지에 분산된 산화물 입자의 미세조직을 HRTEM으로 관찰한 결과 산화물과 기지 계면의 일정 부분에서 결함이 발생된 영역이 확인되었다(그 림 2(c)). 이는 높은 에너지 가공으로 $\mathrm{Fe}$ 및 $\mathrm{Y}_{2} \mathrm{O}_{3}$ 분말이 합금 화 되는 과정에서 원소 간 비평형상태의 계면 결함이 발생된 것으로 판단된다 [24,25]. HRTEM 이미지를 FFT 패턴으로 분석하면 $\mathrm{Y}_{2} \mathrm{O}_{3}$ 산화물의 결정구조와 가장 일치하였고 (321) $\mathrm{Y}_{2} \mathrm{O}_{3},(613) \mathrm{Y}_{2} \mathrm{O}_{3},(332) \mathrm{Y}_{2} \mathrm{O}_{3}$, 및 (110)Fe 결정면이 관찰 되었다. 합금 분말의 미세조직을 분석한 결과, 기계적 합금화
공정으로 $\mathrm{Fe}$ 및 $\mathrm{Y}_{2} \mathrm{O}_{3}$ 분말은 미세화되면서 $\mathrm{Y}$-rich와 Fe-rich 성분으로 구성된 산화물 입자가 생성되고 기지에 분산되는 것으로 요약된다. 이렇게 제조된 합금 분말은 원자 결함이나 불규칙상의 계면이 형성되므로 높은 에너지가 축적된 준안 정상태로 추측된다.

\section{2. 온도 상승에 따른 산화물의 미세조직}

$\mathrm{Fe}-5 \mathrm{Y}_{2} \mathrm{O}_{3}$ 분말을 상온에서 $1050{ }^{\circ} \mathrm{C}$ 까지 승온하는 과정에 서 발생되는 미세조직 변화를 in-situ TEM으로 실시간 관찰 하여 그림 3 에 나타내었다. 상온에서 관찰한 합금 분말의 미 세조직은 기공이 다량 함유된 기지에 산화물 입자가 분포되 어 있었다. 상온부터 온도가 상승하면서 입자들의 확산 반응 이 관찰되었고 $500{ }^{\circ} \mathrm{C}$ 이상의 온도에서는 확산 속도가 증가 되었다. 온도가 $600{ }^{\circ} \mathrm{C}$ 까지 상승하면서 기지에 다량 관찰되 었던 기공이 대부분 소멸되었고 입자가 성장되었다(그림 3(a-d)). 온도가 상승하면서 입자의 확산 속도가 증가되고 입 자 성장이 가속화되면서 결정립이 성장하는 것으로 판단된 다. $700{ }^{\circ} \mathrm{C}$ 로 승온되면서 결정립이 계속 성장되고 $800{ }^{\circ} \mathrm{C}$ 이 상으로 온도가 상승하자 Y-rich 및 Fe-rich 입자 사이의 상호 확산 반응이 관찰되었다(그림 3(e-f)). Y-rich 및 Fe-rich 성분 으로 구성된 산화물에서 새로운 결정화 반응이 발생하는 것 으로 판단된다. 온도가 $900{ }^{\circ} \mathrm{C}$ 까지 상승하면서 마치 핵생성 과 같은 반응이 발생하였고 Y-rich 영역 내부에 나노 크기의 입자 형상이 관찰되었다(그림 $3(\mathrm{~g})) .1000^{\circ} \mathrm{C}$ 온도에서는 Fe-rich 입자의 확산 속도가 감소된 반면, Y-rich 산화물 입자 내부에 형성된 작은 구형의 입자들이 성장하는 현상이 관찰 되었다(그림 3(h)). 이는 Y-rich 및 Fe-rich 입자 사이의 원소 간 확산 반응으로 인하여 원자가 재배열 된 것으로 생각된다. 이러한 현상이 $1050{ }^{\circ} \mathrm{C}$ 온도 부근까지 지속되었고 이로 인해 새로운 형태의 산화물 입자들이 관찰되었다(그림 3(i)). 기존 $\mathrm{DSC}$ 분석 결과에서 $1054{ }^{\circ} \mathrm{C}$ 온도 부근에서 발열반응이 관찰 되어 산화물 결정상 변화가 발생되었다고 보고하고 있다 [26]. 따라서 in-situ TEM으로 관찰된 입자는 기계적 합금화 공정에서 형성된 산화물 입자가 온도가 상승하면서 상변태 에 의해 산화물 입자내에 미세한 산화물이 다량 형성된 것으 로 판단된다. 제조된 $\mathrm{Fe}-5 \mathrm{Y}_{2} \mathrm{O}_{3}$ 합금 분말의 열처리 과정을 살펴보면, 온도가 상승하면서 확산에 의해 결정립 성장이 관 찰되고, 약 $800{ }^{\circ} \mathrm{C}$ 온도까지 상승하면 Y-rich 및 F-rich 입자 간 상호 확산 반응이 관찰된다. $900{ }^{\circ} \mathrm{C}$ 온도 부근에서는 Y-rich 산화물 입자 내부에 수 나노 크기의 미세한 입자가 형 성되는 핵생성 현상이 발생되며 약 $1000{ }^{\circ} \mathrm{C}$ 부근의 온도에서 


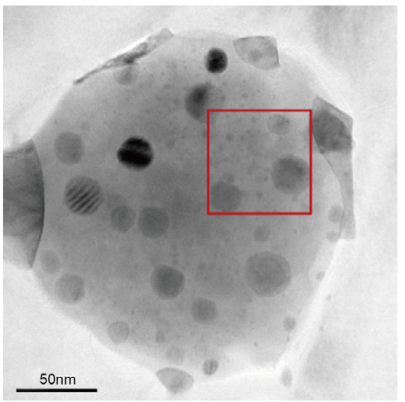

(a)

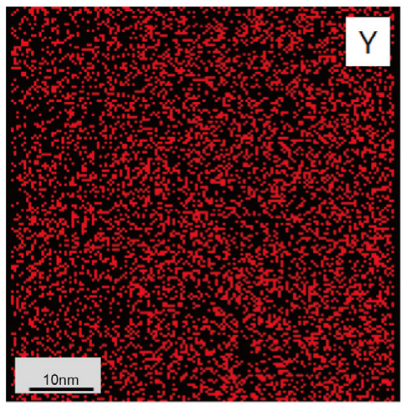

(c)

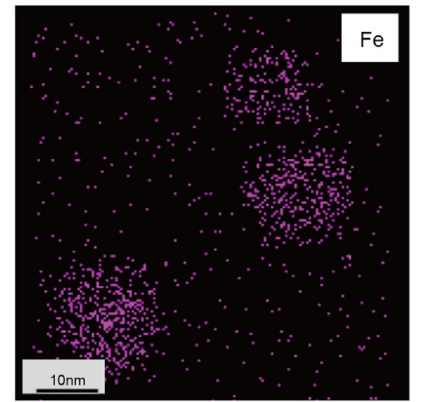

(b)

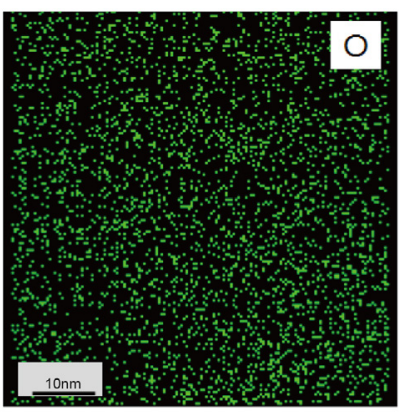

(d)
Fig. 4. TEM/EDS study results of the mechanically alloyed $\mathrm{Fe}-5 \mathrm{Y}_{2} \mathrm{O}_{3}$ powder after heating; (a) TEM image and EDS mapping images of (b) Fe, (c) $\mathrm{Y}$ and (d) $\mathrm{O}$.

는 형성된 입자가 구형으로 성장한다. 이는 열처리 과정에서 새로운 구조의 산화물 입자가 생성되는 것으로 판단된다. 높 은 에너지가 축적된 $\mathrm{Fe}-5 \mathrm{Y}_{2} \mathrm{O}_{3}$ 합금화 분말은 온도가 상승하 는 과정에서 Y-rich 및 F-rich 산화물 입자의 확산과 재분배 반응이 발생하고 이로 인해 산화물이 재결정화 되는 것으로 해석된다. 또한 새롭게 형성된 미세한 입자는 안정화되기 위 해 구형의 형상으로 성장하는 것으로 예상된다. 즉, 준안정상 태의 합금 분말에 열에너지가 공급되면서 기지에 분산되어 있던 Y-rich 및 F-rich 산화물 입자의 확산 거동이 발생하고 원자가 재배열 되면서 새로운 결정구조 산화물 입자가 석출 되는 것으로 판단된다.

온도가 $1050{ }^{\circ} \mathrm{C}$ 까지 상승 한 후 형성된 산화물 입자의 화 학 성분 분석 결과는 그림 4 와 같다. In-situ TEM 분석 결과에 서도 알 수 있듯이, 약 $200 \mathrm{~nm}$ 의 입도를 가지는 산화물 입자 내부에 약 $10 \mathrm{~nm}$ 정도 크기의 미세한 입자들이 존재하고 있 었다(그림 4(a)). EDS mapping으로 일정 부분의 화학 성분을 분석하면 산화물 내부에 존재하는 미세한 입자는 Fe-rich 입 자로 분석되었고(그림 4(b)), Y 성분(그림 4(c))과 $\mathrm{O}$ 성분(그 림 4(d))은 비교적 균일하게 분포되었다. 온도가 상승하면서 산화물 계면 부분에 존재하던 Fe-rich 입자는 산화물 내부로

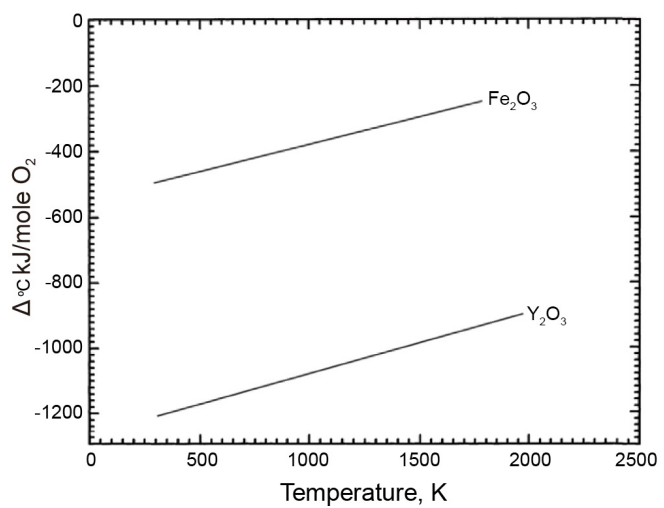

Fig. 5. Standard free energy of formation of $\mathrm{Fe}_{2} \mathrm{O}_{3}$ and $\mathrm{Y}_{2} \mathrm{O}_{3}$ as a function of temperatures.

확산되었고 Y-rich 입자와 반응하면서 안정화되기 위해 구형 의 산화물을 형성시킨 것으로 판단된다. 이는 $\mathrm{Fe}$ 분말과 $\mathrm{Y}_{2} \mathrm{O}_{3}$ 분말이 기계적 합금화 및 열처리 공정으로 $\mathrm{Y}-\mathrm{Fe}-\mathrm{O}$ 구 조의 새로운 산화물이 형성된 것으로 해석되며, 이러한 사실 은 주목할 만한 결과라고 여겨진다. 기계적 합금화 분말의 미 세조직을 상온에서 관찰하면 기지 내 단일 석출물이 분산되 어 있는 것으로 관찰된다. 하지만 실질적으로는 결정구조가 변경된 $\mathrm{Y}_{2} \mathrm{O}_{3}$ 산화물이 존재하고 있으며 열처리 과정에서 온 도가 상승하면서 $\mathrm{Y}-\mathrm{Fe}-\mathrm{O}$ 형태의 산화물 입자로 변화하는 것 으로 판단된다. 기계적 합금화 분말의 열처리 과정 분석 결과 를 종합해 보면, $\mathrm{Fe}-5 \mathrm{Y}_{2} \mathrm{O}_{3}$ 합금 분말이 제조되는 과정에서 Y-rich, Fe-rich 두 종류의 성분으로 구성되어 있는 산화물이 형성되고 높은 에너지가 축적된 합금 분말이 제조된다. 이러 한 합금 분말에 열에너지가 공급되면, 핵생성 과정과 같은 원 자 확산과 재분배 및 재결정화 반응이 발생된다. 이로 인해 새로운 결정구조의 산화물로 상변태되는 것으로 판단된다.

그림 5는 $\mathrm{Fe}_{2} \mathrm{O}_{3}, \mathrm{Y}_{2} \mathrm{O}_{3}$ 의 온도별 생성자유에너지 값을 보여 주는 그래프이다. 자유도 값은 음의 값을 나타내고 있으며, $\mathrm{Fe}_{2} \mathrm{O}_{3}$ 원소에 비해 $\mathrm{Y}_{2} \mathrm{O}_{3}$ 원소의 자유도가 비교적 매우 낮다 는 것을 알 수 있다. $\gamma$ - $\mathrm{Fe}$ 기지에서 $\mathrm{Fe}$ 원소의 확산 속도는 $900{ }^{\circ} \mathrm{C}$ 온도에서 $1.1 \times 10^{-17} \mathrm{~m}^{2} / \mathrm{s}$ 이며, $1100{ }^{\circ} \mathrm{C}$ 온도에서는 $7.8 \times 10^{-16} \mathrm{~m}^{2} / \mathrm{s}$ 이다. 합금 분말을 열처리하면, 자유도가 비교 적 높은 $\mathrm{Fe}$ 원소가 우선적으로 확산되고 온도가 증가함에 따 라 원자들의 핵생성 및 확산 반응이 활발하게 진행될 것으로 예상된다. 특히 기계적 합금화 공정으로 $\mathrm{Fe}, \mathrm{Y}_{2} \mathrm{O}_{3}$ 분말이 파 쇄되고 혼합되는 과정이 반복되면서 높은 에너지가 축적되 고 전위나 공공 및 결함과 같은 원자들의 핵생성 위치 및 확 산 경로를 충분하게 제공받게 될 것으로 예상된다. 


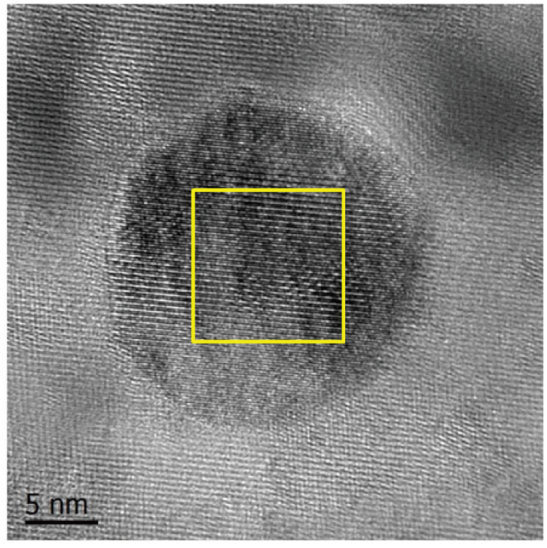

(a)

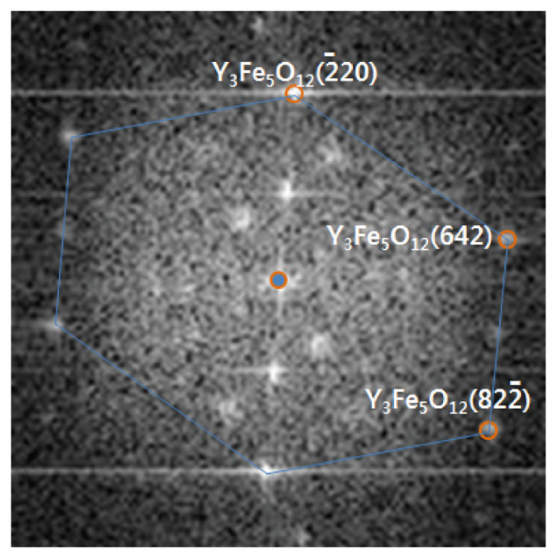

(b)

Fig. 6. HRTEM study results of $\mathrm{Y}-\mathrm{Fe}-\mathrm{O}$ structure phase and matrix in $\mathrm{Fe}-5 \mathrm{Y}_{2} \mathrm{O}_{3}$ alloy after heating at $1050^{\circ} \mathrm{C}$; (a) HRTEM image and (b) FFT pattern analysis.

\section{3. 미세산화물의 결정구조}

$1050{ }^{\circ} \mathrm{C}$ 온도에서 열처리한 후 분말에 존재하는 산화물의 미세조직을 HRTEM 이미지로 관찰한 다음 FFT 패턴을 해석 한 결과는 그림 6과 같다. 산화물 입자는 약 $20 \mathrm{~nm}$ 입도로 관 찰되었다(그림 6(a)). HRTEM 이미지를 FFT 패턴으로 indexing 하면 산화물의 결정구조는 $\mathrm{Y}_{3} \mathrm{Fe}_{5} \mathrm{O}_{12}$ 산화물과 가장 유사한 구조였으며, 산화물 결정면은 (220) Y3Fe5O12, (642) Y3Fe5O12, $_{2}$ (822)Y3Fe5O12과 일치하였다(그림 6(b)). 합금 분말의 열처리 과정과 화학 성분 분석 결과에서 알 수 있듯이, $\mathrm{Y}-\mathrm{Fe}-\mathrm{O}$ 와 같 은 원자 구조의 산화물이 형성된 결과로 판단된다. 기계적 합 금화 공정으로 입자에 전위나 공공과 같은 결함이 발생되었 고, 열처리 과정에서 산화물의 결합에너지가 변하고 결합 구 조의 재배열로 인한 새로운 구조의 클러스터가 형성된 것으 로 예상된다. $\mathrm{Fe}, \mathrm{Y}_{2} \mathrm{O}_{3}$ 두 종류 원소의 화학 반응식은 다음 주 어진 식과 같다 $[27,28]$. 기계적 합금화 분말은 열처리 과정에
서 식(1) 및 식(2)와 같은 화학 반응과 같은 과정으로 Y-rich 입자, Fe-rich 입자, 공공 및 과잉 산소들이 결합되면서 새로 운 형태의 입자가 결정화되는 것으로 예상된다.

$$
\begin{aligned}
& \frac{1}{2} \mathrm{Y}_{2} \mathrm{O}_{3}+\frac{1}{2} \mathrm{Fe}_{2} \mathrm{O}_{3}+\mathrm{Ex} \cdot \mathrm{O} \rightarrow \mathrm{YFe}_{e-\delta} \\
& \frac{3}{2} \mathrm{Y}_{2} \mathrm{O}_{3}+\frac{5}{2} \mathrm{Fe}_{2} \mathrm{O}_{3}+\mathrm{Ex} \cdot \mathrm{O} \rightarrow \mathrm{Y}_{3} \mathrm{Fe}_{5} \mathrm{O}_{12-\theta}
\end{aligned}
$$

기계적 합금화 분말의 열처리 영향을 열역학적 특성으로 고려해 보면, 합금화 분말에 열원이 공급되면서 Y-rich, F-rich 입자에서 핵생성이 발생되고 확산속도가 증가한다. 온 도가 약 $1000{ }^{\circ} \mathrm{C}$ 가 되면 $\mathrm{Y}_{\alpha} \mathrm{Fe}_{\beta} \mathrm{O}_{\gamma}$ 형태의 결정구조 산화물이 생성되는 것으로 판단된다. 즉, $\mathrm{Fe}$ 및 $\mathrm{Y}_{2} \mathrm{O}_{3}$ 분말을 기계적 합 금화하면 $\mathrm{Y}_{2} \mathrm{O}_{3}$ 산화물은 높은 에너지 가공으로 비화학양론 적 결합의 산화물 형태로 $\mathrm{Fe}$ 기지에 분산되고 열처리 공정 중 주변 원소, 공공 및 과잉 산소 등과 재결합되는 과정을 거치 면서 $\mathrm{Y}_{3} \mathrm{Fe}_{5} \mathrm{O}_{12}$ 형태와 유사한 산화물이 생성된 것으로 해석 된다.

\section{4. 결 론}

본 연구에서는 기계적 합금화한 $\mathrm{Fe}-5 \mathrm{Y}_{2} \mathrm{O}_{3}$ 분말에 형성된 산화물 입자의 열처리 거동을 분석하였다. $\mathrm{Fe}$ 와 $\mathrm{Y}_{2} \mathrm{O}_{3}$ 분말은 높은 가공 에너지에 의해 미세화되고 산화물 입자들이 기지 에 분산되었다. 산화물 입자 일부는 Y-rich와 F-rich 두 종류 의 화학 성분으로 구성되어 있었으며, 높은 가공 에너지에 의 해 산화물입자와 기지와의 계면 일부분에 결함이 관찰되었 다. 열처리 과정에서 Y-rich 입자와 Fe-rich 산화물 입자가 상 호 확산되고 재분배되는 반응 과정으로 새로운 미세산화물 입자로 결정화되었다. $1050{ }^{\circ} \mathrm{C}$ 에서 열처리 한 시편에서는 $\mathrm{Y}_{3} \mathrm{Fe}_{5} \mathrm{O}_{12}$ 결정구조의 나노 산화물이 관찰되었다. $\mathrm{Fe}-5 \mathrm{Y}_{2} \mathrm{O}_{3}$ 합금화 분말에서 산화물의 열처리 거동을 요약해 보면, 기계 적 합금화 공정 중에 높은 에너지가 축적된 Y-rich 및 Fe-rich 성분으로 구성된 산화물 입자가 기지에 분산된다. 열처리 과 정에서 Y-rich 및 Fe-rich 산화물 입자에 핵생성과 확산반응 이 발생하고 공공 및 과잉 산소 등과 재결합하면서 결정화된 다. 이로 인해 5 50 nm 입도 크기를 가지는 $\mathrm{Y}_{\alpha} \mathrm{Fe}_{\beta} \mathrm{O}_{\gamma}$ 결정구 조의 새로운 산화물이 생성된다. 이러한 연구 결과는 고강도 $\mathrm{ODS}$ 신합금을 개발하는 과정에서 제조 공정 과정을 최적화 
하는데 유용하게 활용될 것으로 기대된다.

\section{감사의 글}

이 논문은 2015년도 정부(미래창조과학부)의 재원으로 한

국연구재단의 지원을 받아 수행된 연구(원자력안전, No.

2017M2A8A4017639)이며, 이에 감사드립니다.

\section{REFERENCES}

1. T. K. Kim, S. Noh, S. H. Kang, J. J. Park, H. J. Jin, M. K. Lee, J. Jang, and C. K. Rhee, Nucl. Eng. Technol. 48, 572 (2016).

2. T. K. Kim, J. H. Baek, C. H Han, S. H. Kim, and C. B. Lee, J. Nucl. Mater. 389, 359 (2009).

3. T. K. Kim, S. Noh, S. H. Kang, H. J. Jin, and G. E. Kim, World J. Eng. Technol. 3, 125 (2015).

4. S. Noh, J. E. Choi, B. K. Choi, S. H. Kang, and T. K. Kim, Korean J. Met. Mater. 52, 705 (2014).

5. R. Vijay, M. Nagini, S. S. Sarma, M. Ramakrishna, A. V. Reddy, and G. Sundararajan: Metall. Mater. Trans. A 45A, 777 (2014).

6. T. K. Kim and S. H. Kim, J. Nucl. Mater. 1-3, 208 (2011).

7. Y. H. Jeong, W. J. Kim, D. J. Kim, J. Jang, S. H. Kang, Y. B. Chun, and T. K. Kim, Procedia Eng. 86, 1 (2014).

8. H. Sakasegawa, M. Tamura, S. Ohtsuka, S. Ukai, H. Tanigawa, A. Kohyama, and M. Fujiwara, J. Alloys Compd. 452, 2 (2008).

9. T. K. Kim, C. H. Han, S. H. Kang, S. Noh, and J. Jang, Curr. Nanosci. 10, 94 (2014).

10. D. T. Holzer, B. A. Pint, and I. G. Wright, J. Nucl. Mater. 283, 1306 (2000).

11. S. Noh, B. K. Choi, S. H. Kang, and T. K. Kim, Nucl. Eng. Technol. 46, 857 (2014).
12. A. Hirata, T. Rujita, Y. R. Wen, J. H. Scheneibel, C. T. Liu, and M. W. chen, Nat. Mater. 10, 922 (2011).

13. C. A. Williams, P. Unifantowicz, N. baluc, G. D. W. Smith, and E. A. Marquis, Acta Mater. 61, 2219 (2013).

14. S. Ukai and M. Fujiwara, J. Nucl. Mater. 307-311, 749 (2002).

15. L. L. Hsiung, M. J. Fluss, and A. Kimura, Mater. Lett. 64, 1782 (2010).

16. P. He, T. Liu, A. Moslang, R. Lindau, R. Ziegler, J. Hoffmann, P. Kurinskiy, L. Commin, P. Vladimirov, S. Nikitenko, and M. silveir, Mater. Chem. Phys. 136, 990 (2012).

17. X. Mao, T. K. Kim, S. S. Kim, Y. S. Han, K. H. Oh, and J. Jang, J. Nucl. Mater. 461, 329 (2015).

18. M. L. Lescoat, J. Ribis, Y. Chen, E. A. Marquis, E. Bordas, P. Trocellier, Y. Serruys, A. Gentils, O. Kaitasov, Y. D. Carlan, and A. Legris, Acta Mater. 78, 328 (2014).

19. X. Mao, K. H. Oh, S. H. Kang, T. K. Kim, and J. Jang, Acta Mater. 89, 141 (2015).

20. I. Hilger, X. Boulnat, J. Hoffmann, C. Testani, F. Bergner, Y. De Carlan, F. Ferraro, and A. Ulbricht, J. Nucl. Mater. 206-214, 472 (2016).

21. P. K. Parida, A. Dasgupta, K. Jayasankar, M. Kamurddin, and S. Saroja, J. Nucl. Mater. 441, 331 (2013).

22. G. Ressel, D. Holec, A. Fian, F. M. Martin, and H. Leitner, Appl. Phys. A 115, 851 (2014).

23. G. E. Kim, Y. D. Kim, S. Noh, and T. K. Kim, Korean J. Met. Mater. 54, 533 (2016).

24. T. Liu, H. Shen, C. Wang, and W. Chou, Prog. Nat. Sci. Mater. Int. 23, 434 (2013).

25. X. Boulnat, M. Perez, D. Fabregue, S. Cazottes, and Y. de Carlan, Acta Mater. 107, 390 (2016).

26. G. E. Kim, S. Noh, J. E. Chio, Y. D. Kim, and T. K. Kim, J. Korean Powder Metall. Inst. 22, 46 (2015).

27. K. T. Jacob and G. Rajitha, Solid State Ionics. 224, 32 (2012).

28. M. Brocq, B. Radiguet, J. M. Le Breton, F. Cuvilly, P. Pareige, and F. Legendre, Acta Mater. 581806 (2010). 